\title{
Distribution of Dental Diseases and Treatment Delivered amongst Patients Visiting Dental Outpatient Department at Gandaki Medical College, Nepal
}

\author{
Tuladhar $\mathrm{SL}^{1^{*}}$, Parajuli $\mathrm{U}^{2}$, Manandhar $\mathrm{P}^{1}$, Subedi $\mathrm{N}^{3}$, Kunwar $\mathrm{D}^{4}$ \\ ${ }^{1}$ Lecturer, Department of Prosthodontics, ${ }^{2}$ Associate Professor, Department of Orthodontics, \\ ${ }^{3}$ Associate Professor, Department of Forensic Medicine, \\ ${ }^{4}$ Lecturer, Department of Conservative and Endodontics, \\ College of Dental Surgery, Gandaki Medical College, Lekhnath, Pokhara, Kaski, Nepal
}

\author{
Keywords \\ Dental diseases, Distribution, Treatment.

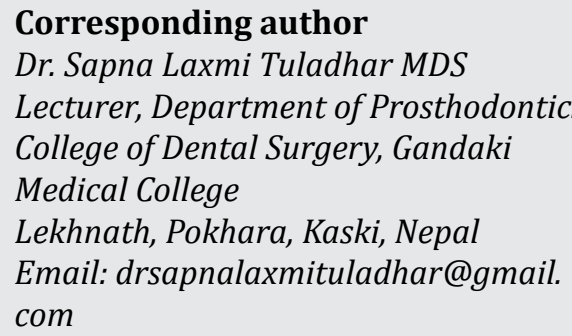

\begin{abstract}
Introduction: A study of dental diseases amongst patients attending dental outpatient department (OPD) helps us plan a preventive, and/or a definitive dental treatment.
\end{abstract}

Objectives: To find out the distribution of dental diseases amongst patients visiting dental OPD at College of Dental Surgery, Gandaki Medical College (GMC), Pokhara, Nepal.

Methods: The present study was a hospital based cross sectional descriptive study carried out during a period of one year extending from $1^{\text {st }}$ February 2016 to $31^{\text {st }}$ January 2017. A total of 3052 patients attending the dental OPD were included in the study. The distribution of dental diseases according to sex, age and diagnosis were collected and analyzed. Additionally, frequency distribution of treatments provided to the patients was observed.

Results: Dental caries was the most prevalent dental disease (64.41\%) followed by gingivitis (13.04\%). The prevalence of dental caries was significantly higher in females (Females $56.91 \%$ vs. males $43.08 \%, \mathrm{P}<0.05)$. Conversely, the prevalence of maxillofacial injuries (85.06\%), dental impactions (72\%), and malocclusion (53.88\%) were significantly more common in male patients $(\mathrm{P}<0.05)$. The age group $\leq 19$ years comprised $23.98 \%$ of patients who visited the dental OPD, and the dental caries was most prevalent $(27.10 \%)$ in the age group. The order of more frequent dental treatments was root canal treatment (18.84\%), tooth extraction (18.44\%), dental restoration (10.48\%), and scaling (9.20\%).

Conclusions: The most prevalent dental disease was dental caries and it was more prevalent in females than in males. The most common age group reporting to Dental OPD was $\leq 19$ years.

\section{INTRODUCTION}

Knowledge of a pattern of dental diseases among patients attending a dental OPD is essential to plan a proper preventive and therapeutic dental treatment. Worldwide
$100 \%$ of the adults and $60-90 \%$ of the school children have dental caries ${ }^{1}$. Oral disease is a major public health problem which leads to higher prevalence and significant social impact ${ }^{2}$. 
Based on a previous study conducted in Nepal, dental caries was the most prevalent dental disease followed by periodontitis, pericoronal abscess, chronic gingivitis, malocclusion, trauma, cyst, and others ${ }^{3}$.

This study aimed to find out the distribution of diseases among the patients at dental OPD of GMC. Such studies will help us to know the prevalence of dental diseases locally, which can be compared with other population. As Nepal has entered the Federal system of Government and decentralization such studies will help us to formulate policies for uplift men of oral health in the province.-

\section{METHODS}

This is a hospital based cross sectional descriptive study carried out at dental outpatient department of Gandaki Medical College Teaching Hospital and Research Center, Pokhara, Nepal. The duration of study was a period of one year from $1^{\text {st }}$ Feb 2016 to $31^{\text {st }}$ Jan 2017. All the patients attending dental OPD were screened after obtaining consent. Those patients who denied giving the consent were excluded from the study. Total 3052 patients were screened. Data relating to age, sex, diagnosis and treatment rendered were obtained. The obtained data were entered in Microsoft Excel 2003 and further analyzed by SPSS version 25. The distribution of patients according to age, sex and diagnosis was calculated. The percentage of distribution and Pearson Chi Square test with 5\% level of significance was applied to look for differences in disease distribution according to sex. The percentage for treatments delivered was calculated.

\section{RESULTS}

A total of 3052 patients attending the dental OPD were screened. Table 1 show that out of total patients, 1558 (51.05\%) were males and 1494 (48.95\%) were females. The most prevalent dental disease in patients visiting dental OPD was dental caries in $64.41 \%$ followed by gingivitis (13.04\%). The prevalence of dental caries was significantly high amongst females (56.91\%; P value $<0.05)$. While the prevalence of malocclusion (53.88\%), maxillofacial injuries (85.06\%) and impactions (72\%) were more common amongst male patients $(\mathrm{P}$ value,
$0.05)$.

Table 1: Dental Diseases and distribution according to sex

\begin{tabular}{|c|c|c|c|c|}
\hline $\begin{array}{l}\text { Dental Dis- } \\
\text { eases }\end{array}$ & $\begin{array}{l}\text { Males } \\
\text { N (\%) }\end{array}$ & $\begin{array}{c}\text { Females } \\
\mathrm{N}(\%)\end{array}$ & $\begin{array}{l}\text { Total } \\
\text { N (\%) }\end{array}$ & $\begin{array}{c}\text { P- } \\
\text { value* }\end{array}$ \\
\hline $\begin{array}{l}\text { Dental } \\
\text { Caries }\end{array}$ & $\begin{array}{c}847 \\
(43.80 \%)\end{array}$ & $\begin{array}{c}1119 \\
(56.91 \%)\end{array}$ & $\begin{array}{c}1966 \\
(64.41 \%)\end{array}$ & $<0.001$ \\
\hline Gingivitis & $\begin{array}{c}278 \\
(69.85 \%)\end{array}$ & $\begin{array}{c}120 \\
(30.15 \%)\end{array}$ & $\begin{array}{c}398 \\
(13.04 \%)\end{array}$ & 0.74 \\
\hline Periodontitis & $\begin{array}{c}22 \\
(53.66 \%)\end{array}$ & $\begin{array}{c}19 \\
(46.34 \%)\end{array}$ & $\begin{array}{c}41 \\
(1.34 \%)\end{array}$ & 0.38 \\
\hline Malocclusion & $\begin{array}{c}118 \\
(53.88 \%)\end{array}$ & $\begin{array}{c}101 \\
(46.12 \%)\end{array}$ & $\begin{array}{c}219 \\
(7.18 \%)\end{array}$ & $<0.001$ \\
\hline Edentulous & $\begin{array}{c}18 \\
(24.32 \%)\end{array}$ & $\begin{array}{c}56 \\
(75.68 \%)\end{array}$ & $\begin{array}{c}74 \\
(2.42 \%)\end{array}$ & $<0.001$ \\
\hline $\begin{array}{l}\text { Maxillofacial } \\
\text { injuries }\end{array}$ & $\begin{array}{c}131 \\
(85.06 \%)\end{array}$ & $\begin{array}{c}23 \\
(14.94 \%)\end{array}$ & $\begin{array}{c}154 \\
(5.05 \%)\end{array}$ & $<0.001$ \\
\hline Impaction & $\begin{array}{c}144 \\
(72 \%)\end{array}$ & $\begin{array}{c}56 \\
(28 \%)\end{array}$ & $\begin{array}{c}200 \\
(6.55 \%)\end{array}$ & $<0.001$ \\
\hline Total & $\begin{array}{c}1558 \\
(51.05 \%)\end{array}$ & $\begin{array}{c}1494 \\
(48.95 \%)\end{array}$ & $\begin{array}{c}3052 \\
(100.00 \%)\end{array}$ & \\
\hline *P value taker & Pem Pearso & Thi Souare & & \\
\hline
\end{tabular}

The distribution of dental diseases according to age (Table 2) showed that age group $\leq 19$ years visited the dental OPD most which was $23.98 \%$ out of total. Dental caries was more prevalent in age group $\leq 19$ years (27.10\%), gingivitis in age group 40 to 49 years $(24.87 \%)$, periodontitis in age group $\geq 60$ years (24.39), malocclusion in age group $\leq 19$ years (43.84), partially edentulous in age group $\geq 60$ years (32.43\%), maxillofacial injuries in age $\leq 19$ years $(27.92 \%)$ and impaction in age group 20 to 29 years $(59.5 \%)$.

Fig 1 shows that the maximum number of patients just did checkup (32.63\%) followed by root canal treatments 
(18.84\%) and extractions (18.45\%).

Table 2: Dental Diseases according to age groups

\begin{tabular}{|c|c|c|c|c|c|c|c|}
\hline \multirow{2}{*}{$\begin{array}{l}\text { Dental } \\
\text { Diseases }\end{array}$} & \multicolumn{6}{|c|}{ Age group ( Years) N (\%) } & \multirow[b]{2}{*}{ Total } \\
\hline & $\leq 19(\%)$ & $\begin{array}{c}20-29 \\
(\%)\end{array}$ & $\begin{array}{c}30-39 \\
(\%)\end{array}$ & $\begin{array}{c}40-49 \\
(\%)\end{array}$ & $\begin{array}{c}50-59 \\
(\%)\end{array}$ & $\geq 60(\%)$ & \\
\hline $\begin{array}{l}\text { Dental } \\
\text { Caries }\end{array}$ & $\begin{array}{c}541 \\
(27.10)\end{array}$ & $\begin{array}{c}286 \\
(14.33)\end{array}$ & $\begin{array}{c}256 \\
(12.83)\end{array}$ & $\begin{array}{c}238 \\
(11.92)\end{array}$ & $\begin{array}{c}393 \\
(19.69)\end{array}$ & $\begin{array}{c}252 \\
(12.63)\end{array}$ & 1996 \\
\hline Gingivitis & $\begin{array}{c}49 \\
(12.31)\end{array}$ & $\begin{array}{c}72 \\
(18.09)\end{array}$ & $\begin{array}{c}69 \\
(17.34)\end{array}$ & $\begin{array}{c}99 \\
(24.87)\end{array}$ & $\begin{array}{c}39 \\
(9.80)\end{array}$ & $\begin{array}{c}70 \\
(17.59)\end{array}$ & 398 \\
\hline $\begin{array}{l}\text { Periodon- } \\
\text { titis }\end{array}$ & $\begin{array}{c}0 \\
(0)\end{array}$ & $\begin{array}{c}6 \\
(14.63)\end{array}$ & $\begin{array}{c}4 \\
(9.76)\end{array}$ & $\begin{array}{c}9 \\
(21.95)\end{array}$ & $\begin{array}{c}12 \\
(29.27)\end{array}$ & $\begin{array}{c}10 \\
(24.39)\end{array}$ & 41 \\
\hline $\begin{array}{l}\text { Malocclu- } \\
\text { sion }\end{array}$ & $\begin{array}{c}96 \\
(43.84)\end{array}$ & $\begin{array}{c}85 \\
(38.81)\end{array}$ & $\begin{array}{c}38 \\
(17.35)\end{array}$ & $\begin{array}{c}0 \\
(0)\end{array}$ & $\begin{array}{c}0 \\
(0)\end{array}$ & $\begin{array}{c}0 \\
(0)\end{array}$ & 219 \\
\hline $\begin{array}{l}\text { Edentu- } \\
\text { lous }\end{array}$ & $\begin{array}{c}3 \\
(4.05)\end{array}$ & $\begin{array}{c}19 \\
(25.68)\end{array}$ & $\begin{array}{c}5 \\
(6.76)\end{array}$ & $\begin{array}{c}13 \\
(17.57)\end{array}$ & $\begin{array}{c}10 \\
(13.51)\end{array}$ & $\begin{array}{c}24 \\
(32.43)\end{array}$ & 74 \\
\hline $\begin{array}{l}\text { Maxil- } \\
\text { lofacial } \\
\text { injuries }\end{array}$ & $\begin{array}{c}43 \\
(27.92)\end{array}$ & $\begin{array}{c}56 \\
(36.36)\end{array}$ & $\begin{array}{c}20 \\
(12.99)\end{array}$ & $\begin{array}{c}11 \\
(7.14)\end{array}$ & $\begin{array}{c}12 \\
(7.79)\end{array}$ & $\begin{array}{c}12 \\
(7.79)\end{array}$ & 154 \\
\hline Impaction & $\begin{array}{c}0 \\
(0)\end{array}$ & $\begin{array}{c}119 \\
(59.5)\end{array}$ & $\begin{array}{c}60 \\
(30)\end{array}$ & $\begin{array}{c}21 \\
(10.5)\end{array}$ & $\begin{array}{c}0 \\
(0)\end{array}$ & $\begin{array}{c}0 \\
(0)\end{array}$ & 200 \\
\hline Total & $\begin{array}{c}732 \\
(23.98)\end{array}$ & $\begin{array}{c}643 \\
(21.07)\end{array}$ & $\begin{array}{c}452 \\
(14.81)\end{array}$ & $\begin{array}{c}391 \\
(12.81)\end{array}$ & $\begin{array}{c}466 \\
(15.27)\end{array}$ & $\begin{array}{c}368 \\
(12.06)\end{array}$ & 3052 \\
\hline
\end{tabular}

Fig 1: Distribution of treatments delivered

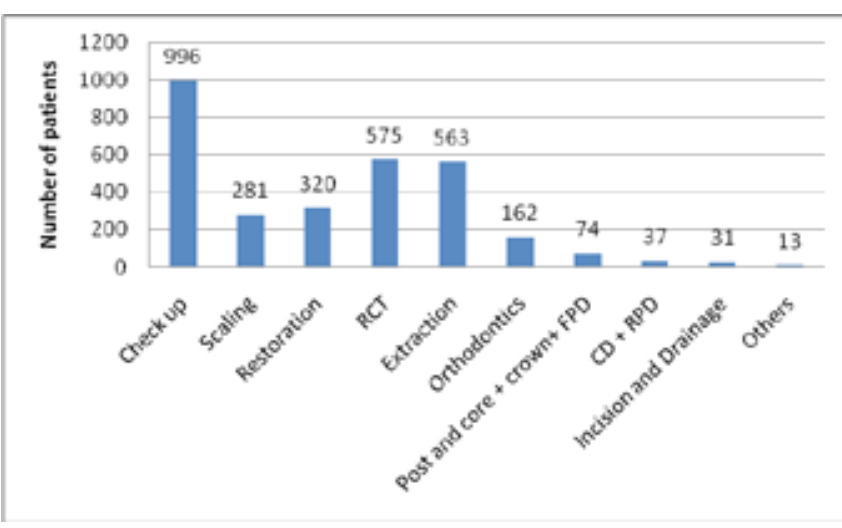

\section{DISCUSSION}

In our study, the most common dental disease was dental caries (64.41\%) and was prevalent in age group $\leq 19$ years which is consistent with the WHO study which shows worldwide 60 to $90 \%$ of school children have cavities ${ }^{1}$. This was also consistent with the National Path finder survey which showed $58 \%$ of the school children suffer from dental caries ${ }^{4,5}$. Our results were comparable with the study done by Hassan $e t ~ a l^{6}$ in Srinagar Hospital with dental caries to be most prevalent (60.3\%).

In our study, the second most prevalent dental disease was gingivitis (13.04\%) but in contrary Hassan $e t a l^{6}$ in their study showed that periodontitis $(18.3 \%)$ as the second prevalent dental diseases. This could have been because the majority of the patients visiting dental OPD in our hospital are of younger group $\leq 19$ years and periodontitis is less prevalent in younger age group.

The finding of Garkoti et al 2015 is consistent with our study both the study showed that dental caries is the most prevalent dental disease followed by gingivitis. They showed dental caries to be $54.54 \%$ followed by gingivitis (37.62\%) which is comparable to ours dental caries (64.41\%) and gingivitis (13.04\%).

In our study the prevalence of dental caries was significantly higher in female population (56.91\%) $(\mathrm{P}<0.05)$ but Garkoti et a $\Gamma$ in their showed almost equal prevalence of caries in male and female patients (50.09 $\%)$.

In our patient group, the prevalence of dental caries (27.10\%), malocclusion (43.84\%) and maxillofacial injuries $(27.92 \%)$ were more in age group $\leq 19$ years. The distribution of malocclusion was similar to the study done by Garkoti et $a l^{7}$ (38.46\%). School oral health awareness program could be effective in our area where the prevalence of preventable dental diseases like dental caries is more common in younger group.

The results of study done by Yadav $\mathrm{K} e t a l^{8}$ in Dhanusha district, Nepal is almost similar to our results. They showed that the prevalence of dental caries was mostly in 15 to 19 years of females (66.32\%) than males (39.70\%).

The majority of patients in our study underwent only checkup (32.63\%), this could be related to decreased compliance to treatment procedures after dental check up. In a study done by Upadhaya C et $a l^{9}$ at Dhulikhel, Nepal more than $56 \%$ of the total teeth extractions were due to dental caries. In our study the percentage of patients undergoing root canal treatment (18.84\%) was marginally more than extractions (18.45\%) which should prove that there is some change in patients' attitude towards saving the teeth with caries.

\section{CONCLUSIONS}

The most prevalent dental disease in patients visiting Dental OPD GMC was dental caries and was more in females than males. The most common age group reporting to Dental OPD was $\leq 19$ years. The maximum number of patients did checkup (32.63\%) followed by root canal treatments $(18.84 \%)$ and extractions $(18.45 \%)$. Considering the most common age group, school oral 
health awareness program could be effective to control the dental disease prevalence.

\section{Acknowledgement}

I would like to acknowledge Dr. Sushil Subedi, Associate Professor, College of Dental surgery, GMC, and Dr Shristi Sapkota for helping with the data collection. I would like to thank Prof. Dr. Ishwari Sharma Paudel, HOD, Dept. of Community Medicine, GMC and Mr. Ishwari Bhandari, Lecturer Dept. of Community Medicine GMC for helping with the statistical section.

\section{REFERENCES}

1. World Health Organization. Oral Health fact sheet April 2012. Available at http://www.who.int/oral_ health/publications/factsheet/en/. [Assessed on April 29 2018]

2. Humagain M. Evaluation of knowledge, attitude and practice (KAP) about oral health among secondary level students of rural Nepal - A questionnaire study. Webmed Central Dentistry. 2011; 2(3): WMC001805.

3. Rauniar GP, Shahanas MS, Das BP, Naga Rani MA. A prospective study of dental disease pattern and drug utilization at the Dental Department of a Tertiary
Care Teaching Hospital in Eastern Nepal. J Nepal Med Assoc. 2001; 40: 6-11.

4. Yee R, Mishra P. Nepal National Oral Health Pathfinder Survey 2004. J Nepal Dent Assoc. 2005; 7(1): 64-8.

5. Yee R, McDonald N. Caries experience of 5 - 6 year old and 12 - 13 year old school children in Central and Western Nepal. Int Dent J. 2002 Dec; 52(6): 453-60.

6. Hassan S, Hassan AU. A prospective study of dental disease pattern. Int J Clin Surg Adv. 2013; 1(1): 29-32.

7. Garkoti PD, Rawat CMS, Singh RK, Rawat V, Bartwal J, Goyal N. Pattern of dental diseases among patients attending outpatient department of dental: A hospital based cross- sectional study. NJMR. Apr-Jun 2015; 5(2): 112-5.

8. Yadav K, Prakash S, Khanal S, Singh JK. Prevalence of dental caries among adolescence of Dhanusha district, Nepal. Janaki Medical College Journal of Medical Sciences. 2015; 3(2): 29-37.

9. Upadhyaya C, Humagain M. The pattern of tooth loss due to dental caries and periodontal disease among patients attending dental department (OPD), Dhulikhel Hospital, Kathmandu University Teaching Hospital (KUTH), Nepal. Kathmandu Univ Med J. 2009; 7(25): 59-62. 